\title{
The devoloping of studying learning culture and the developing of ICT in pandemic covid-19 in junior high school of rambutan
}

\author{
Roslina Roslina $^{1}$, Edi Harapan ${ }^{2}$, Dessy Wardiah ${ }^{2}$ \\ ${ }^{1}$ Sekolah Menengah Atas Negeri 1 Rambutan, Indonesia \\ ${ }^{2}$ Universitas PGRI Palemban, Indonesia
}

\begin{tabular}{l} 
Article Info \\
\hline Article history: \\
Received Juln $16^{\text {th }}, 2021$ \\
Revised Aug $9^{\text {th }}, 2021$ \\
Accepted Aug $30^{\text {th }}, 2021$
\end{tabular}

\section{Keyword:}

Developing

ICT

Pandemic covid-19

\begin{abstract}
The developing of studying-learning culture in Indonesia nowadays is increased in pandemic era of covid-19, we must face it because this corona virus spread almost in the whole of countries in the world, including Indonesia which have 34 provinces. Having connected with coronavirus, the education that we as Teacher face to the students of course will be problem, the Indonesia Government finally decide to do online class, we call it daring class and using of Information and Communication Technology (ICT) through internet, the students and the teachers have to stay at home, but they are able to learn their lessons via on line by using mobile phone application. Unlucky the students who are from the rich one can do it, they buy the pulse and quota easily but not for the poverty students who can't buy it, it is the obstacle for our education minister to solve the way to help every students in Indonesia doing the education activities. Of course this process doing learning studying so far can run well enough, though we face this pandemic, we really hope it can be over sooner.
\end{abstract}

(C) 2021 The Authors. Published by IICET

This is an open access article under the CC BY-NC-SA license (https://creativecommons.org/licenses/by-nc-sa/4.0

\section{Corresponding Author:}

Roslina, R.,

Sekolah Menengah Atas Negeri 1 Rambutan, Indonesia

Email: ros1231muis@gmail.com

\section{Introduction}

Educating is maturity as a norm that applies universally so that it has its own value. Practically inseparable from cultural values, and in order to maintain and preserve one's own culture, the most effective process of transferring. It is by means of education. From year to year education always changes according to cultural development, because education is a process of cultural transfer ans as a reflection of cultural values which is reflective and also progressive, that is always changes development according to the demands of cultural development, the two characteristics are closely related and integrated. Cultural differences become a mirror for other nations, make differences in system, content and educating of teaching as well as mirror the level of educating and culture [1].

The problem of learing out comes in a school, for example, can't be reparated from the socio-culture and economic conditions of the surrounding community/where students come from, and many other factors out side the school system related to the quality of learning out comes Learning during the current pandemic changes the pattern of education, learning methods and learning culture, from learning at school to distance learning, namely learning from home. 
This is in line whith the functions objectives of national education as stated in law number 20 of 2003 article is which states that distance education (PJJ) is education in various learning sources through communication technology.

\section{Infotmation, and other media}

The government extend the period of learning teaching from home to an idefinite time. Where previously the learning from home policy begun to the implemented on march 9,2020 after the minister of education and culture. Issued circular number 3 of 2020 concerning online learning and working from home in order to prevent the spread of the corona virus this desease or is called covid 19. Holiday studying school does not mean vacation studying at home. All schools are requied to use home learning on line and manually. This wha also emphasized by the minister of education and culture Nadiem Anwar Makarim,BA,MBA through circular number 15 of 2020 instructions to learn from home issued by the central government, one of which is the field of education marked by learning from home or known by the name of distance learning. Daring the covid 19 pandemic, educational institution could only focus on the use of information and communication technology. In the education process at the institutional and payless attention to other aspects of the educational process [2]. In circular number 4 of 2020 concerning the implementation in the emergency period of the corona virus desease covid 19 point 2 explains that the learning process from home is carried out to provide a meaning pol learning experience for student without completing currciculum achievements for class advancement or graduation, one of the main points important in this circular is decision to cancel 2020 national exam (UN).

Since the enactment of social distancing has had an impact on the world of education in Indonesia, the Minister of Education and Culture (MENDIKBUD) Nadiem Makarim supports the policy set by the local government to close schools due to a very worrying situation, almost all parents in Indonesia at this time, parents get tangung responsible for accompanying children to learn from home. Many parents admit that explaining various subjects and accompanying their children on school assignments is not as easy as one might imagine [3].

Learning innovations in dealing with this covid period during home lessons are very much needed. explained in the education and culture room of Kompas newspaper 1september 2020, educators hope that the government will decide on a policy to line up accurate data on school conditions in order to create a comprehensive distance learning solution. the online education system is not easy. In addition to the personal discipline of independent study, there are facilities and resources to differentiate. in line with that the world of education realizes that advances in information and communication technology (ICT) have not only entered the world of education. but it is more than that. ICT takes a central role in the transfer of knowledge content (sripoku.com. Palembang) and the application of online learning demands readiness for both parties, either from the provision of educational services or from the students themselves. however, online and distance learning requires qualified and easily accessible technology assistance. (education, news, learning strategies, study tips). The same thing was written in the Indonesian media which stated that:

The hard work of the teachers and lecturers so far deserves appreciation. in the midst of social problems due to the covid outbreak19. we must remain passionate about pursuing and teaching science. Almost no one thought, the face of education would change drastically due to the COVID-19 pandemic. the concept of homeschooling has never been mainstream in the discourse of national education. Although increasingly popular, the application of online learning has been limited to universities and online courses. But the physical distancing policy to decide the spread of the plague, forcing a change from formal education at school to learning from home with the KBMJNE system on a national scale, even this year's national exam had to be abolished (Indonesian media: July 2020) Information technology is the solution online.

\section{Method}

[4] Descriptive research means describing or photographing what is happening to the object under study [4] in written work using literary methods that are descriptive analytica, descriptive abalktic is a method that describes or draws the characteristics of the object under study using data or samples that have been generated as is without carrying out analysis and making general conclusions. 


\section{Results and Discussions}

\section{Change in learning culture}

The change in learning culture during the pandemic changed the way that basic self-learning is carried out face-to-face in school to create irrational learning which is often referred to as daily learning. As for the developments that occurred during the Covid 19 pandemic, the government implemented various systems as a face-to-face learning effort such as:

\section{The distance learning system (PJJ)}

At this time needed for teacher innovation to provide distance learning (pjj) or online (using the internet network) as well as applications used such as zoom, google classroom, what app, teacher room, as well as lessons through TVRI that are prepared. by the government, this is in line with the statement of Mansyur, Rohim (2020) that the online learning model demands creativity and skills of teachers to use technology. covid 19 institutions education can be centered on the use of information and communication technology in educational practices in institutions and pay less attention to other aspects of the educational process [2].

In circular number 4 of 2020, the grace period for implementing education in the emergency period of the corona virus disease (covid19) The functions and objectives of national education are as stipulated in law number 20 of 2003 article 15 which states that long distance education (pjj) is education in which students are separated from educators and using various learning resources through communication technology, information, and other media.

Quoted from guru learning.simpkb regarding long distance learning (pjj) aims to 1) prevent transmission of covid 19, 2) fulfill student learning rights 3) protect from the impact of covid19. Approach by using offline learning and online learning the principle of distance learning, namely) primary health and safety 2) meaningful learning experience 3) focus on life skills education 4) inclusive learning according to age and level 5) varied assignments 6) interactive communication and mutual feedback according to [5]:

The peculiarities of distance learning contained in it are the teroiksah between material development and students. Global networks through online learning and hyoermedia anticipate the reach of learning locations that tend to be separate and remote even though learning is carried out remotely, the teacher is obliged to make a learning plan, this is so that learning practices from home can run smoothly in the lesson plan. must really consider carefully the material to be given, how to convey the material, the tasks that must be done, the time it takes students to complete the assignment. So far, the phenomenon of students being stressed due to heavy assignments and lack of time in doing tugs occurs because teachers do not make good lesson plans from home

2. The odd-even face-to-face learning system in the new normal era different from other areas in Banyuasin district where the author researched the implementation of the new normal on August 26 using the oddeven attendance system. The progress of face-to-face learning is strengthened by school decree number 420.1 / 116 / SMPN1 RBT / 2020 regarding the division of tasks for teachers and employees. as for the learning culture during a pandemic as follows: 2.1 implementation of a health protocol whereby student arrival begins with body temperature measurement 2.2 is required to listen to hands with soap and disinfectant that has been prepared by the school 2.3 mandatory to use a mask 2.4 lessons are carried out face-to-face using the attendance of students with an odd number and the next with an even number.

\section{Development of ICT}

Along with the current conditions, especially during the pandemix era, technology is needed that can simplify all of our work. science education is developing very pestilently. advances in digital technology have a major impact on all fields, including education, [5] educational technology and learning technology in Indonesia began to exist since the mid-1970s, [6] technology is the entire means of providing goods needed for continuity life and comfort of human life. communication tools used by students of SMPN 1Rambutan.

\section{The role of ICT in education}

The role of ICT, especially in learning during the Covid 19 pandemic, which is used by SMPN 1rambutan students, is very helpful in the smoothness of the online learning process. Students can choose to study through a network of applications such as zoom, whatsapp, google classroom, and other applications, according to UNESCO in 2013, there are several benefits or uses of ICT in education which are very important, including: 1 can increase the equality of education 2. facilitate and provide external access to 
education 3. Can practice professionalism of roots in education 5. Improve the quality and quality of learning between teachers and students.

\section{Conclusions}

Learning culture during the pandemic is not the same as face-to-face learning culture because online learning is carried out remotely assisted by ICT facilities such as the internet. so that learning is carried out well. This is not, of course, apart from the mischievous attempt to try various innovations in the role of technology in learning in the pandemix era, which requires education to be carried out at home via online or online, learning activities are carried out online or online, aiming to break the distribution of covid 19.

\section{References}

[1] Normina. Ittihad Jurnal Kopertais Wilayah XI Kalimantan Volume 15 No.28 Oktober 2017 (Diakses 28 Desember 202015.07 wib)

[2]https://palembang.tribunnews.com/2020/08/28/solusi-proses-pembelajaran-di-tengah-pandemik-covid19-membangun-smart-classroom-menggunakan-tpack(dikutip pada tgl 2 Des 2020 pukul 14:30 wib).

[3] Mendikbud. 2020. SE tentang pelaksanaan pendidikan dalam masa darurat covid 19. (diakses 3 Oktober 2020) pukul 8:31 wib https://www.kemdikbud.go.id/main/blog/2020/03/mendikbud-terbitkan-setentang-pelaksanaan-pendidikan-dalam-masa-darurat-covid19

[4] Sugiyono. 2019. Metode Penelitian kwantitatif. Penerbit Alfa Beta Bandung.

[5] Prawiradilaga, Dewi salma.2012. Wawasan Teknologi Pendidikan. Prenadamedia Group. Jakarta

[6] Arizona, Kurniawan. et.all. (2020). Pembelajaran Online Berbasis Proyek Salah Satu Solusi Kegiatan Belajar Mengajar di Tengah Pandemi Covid-19 . Jurnal Ilmiah Profesi Pendidikan. Volume 5 No 1 Mei 2020. (Online) Tersedia :https://jipp.unram.ac.id/index.php/jipp/article/download/111/99. DOI: 10.29303/jipp.v5i1.111 (Diakses : 1 Des 2020)

[7] Rahayu, K. Kusworo, N. Hamda, H. I. Gunawan, And F. Jaya, "Penerapan Video Pembelajaran Berbasis Android Di Masa Pandemi Covid-19," Pekodimas J. Pengabdi. Kpd. Masy., Vol. 1, No. 1, Pp. 1-10, 2021.

[8]Tafano And S. Saputra, "Teknologi Dan Covid: Tantangan Dan Peluang Dalam Melaksanakan Pembelajaran Daring Di Masa Pandemi," Djtechno J. Teknol. Inf., Vol. 2, No. 1, Pp. 45-53, 2021.

[9]M. Qoriah, S. Masitoh, And S. Setyowati, "Analisis Guru Dalam Menjaga Tata Kelola Pembelajaran Pendidikan Anak Usia Dini Selama Pandemi Covid-19," J. Obs. J. Pendidik. Anak Usia Dini, Vol. 6, No. 1, Pp. 549-557, 2021.

[10] Suryatni, L. (2021). Teknologi Pendidikan Sebagai Pelaksanaan Sistem Informasi Dalam Perkuliahan Online Di Masa Pandemi Covid-19. Jsi (Jurnal Sistem Informasi) Universitas Suryadarma, 8(1), 31-46. 